\title{
Formulation of an MSG (Monosodium Glutamate) free Instant vegetable soup mix
}

\author{
C. P. Abeysinghe ${ }^{1}$ and C. K. Illeperuma $a^{2 *}$ \\ ' Postgraduate Institute of Agriculture, University of Peradeniya, Peradeniya. \\ ${ }^{2}$ Department of Food Science \& Technology, Faculty of Agriculture, University of Peradeniya, Peradeniya.
}

Revised: 12 January 2006; Accepted: 28 February 2006

\begin{abstract}
An instant dehydrated vegetable soup mix with no MSG (Monosodium Glutamate) was developed using dried vegetables $(25 \%)$, whey powder $(18 \%)$, lentil powder $(12 \%)$, salt $(12 \%)$, potato flour $(10 \%)$, corn flour $(9 \%)$, tomato powder $(7 \%)$, vegetable fat $(4 \%)$, sugar $(2 \%)$ and spice $\operatorname{mix}(1 \%)$ as the ingredients. The vegetables carrot, cabbage, leeks, onion as well as tomato and potato, lentil, spices (garlic, pepper, onion) and celery were dehydrated in a cross-flow air cabinet dryer using already established procedures. Physico-chemical analysis revealed that the final product possessed $3.8 \%$ moisture, 0.43 water activity, $4.7 \mathrm{pH}, 18 \%$ ash, $16.1 \%$ protein, $55 \%$ carbohydrate, $4.1 \%$ fat, $2.7 \%$ fiber, $0.17 \%$ calcium, $4.6 \%(\mathrm{mg} / \mathrm{g})$ iron and a calorific value of $321 \mathrm{kcal} / \mathrm{g}$. Aerobic plate count of the developed soup mix was within the safe range $\left(2.3 \times 10^{3} \mathrm{cfu} / \mathrm{g}\right)$. A reconstitution ratio of 1:15 produced an acceptable product. Sensory analysis revealed that there was no significant difference in colour $(p=0.7213)$, flavour $(p=0.2662)$, mouth feel $(p=0.9487)$, consistency $(p=0.0568)$ and overall acceptability $(p=0.8061)$ between a commercial soup mix and the MSG free instant soup mix developed in this study.
\end{abstract}

Keywords: Dried vegetables, instant soup, monosodium glutamate, spice mix

\section{INTRODUCTION}

In the modern world, commercially prepared instant soups such as canned, dehydrated and frozen soups have replaced home made soups ${ }^{1}$, as preparing a soup with good appeal is a time consuming process. Dry soup mixes containing vegetables (or meat) in many forms are second in popularity only to canned soup. These soup mixes are popular among institutions and troops in the field because of easy transportation due to reduced weight and longer shelf life. ${ }^{1}$

Any dehydrated soup mix should be rehydratable and cookable within a minimum time period, and should be as nutritious and palatable as canned or frozen products. ${ }^{2}$ In comparison to freshly prepared soup, instant dry soup should also possess desired quality, representing the dominant flavour and aroma of the ingredients used. It is desirable that the product be free from off flavours, off taste, unacceptable aroma, and faulty texture. ${ }^{3}$ Therefore, flavour improvement is one of the essential requirements. Commercially prepared soup mixes are usually made using (MSG) Monosodium Glutamate to enhance desired flavour. ${ }^{3,4}$ MSG restores some of the original flavours, increases palatability and raises overall flavour level while reducing sodium chloride concentration. ${ }^{5}$ Therefore, it is believed that MSG produces a unique taste perception known as "umami" derived from the Japanese word meaning "deliciousness". Altug and Demirag ${ }^{6}$ also suggested that MSG may be used to reduce sodium chloride content of lentil soup by $40 \%$ without losing its palatability. Elderly people can compensate their taste and aroma losses by incorporating MSG into foods. ${ }^{7}$ However, there is still no accepted physiological explanation for its action as a flavour potentiater. ${ }^{8}$

In recent times, use of MSG has been questioned by consumers across the world due to probable adverse effects on health. It has been recorded that millions of people suffer from MSG induced adverse reactions after ingestion of foods containing MSG. It is believed that these reactions may be dose related. Some people develop allergic symptoms on consumption of very minute quantities of MSG. Although the Joint Expert Committee on Food Additives of the Food and Agricultural Organization, United Nations, Food and Drug Administration of the European Community, and the United States Food and Drug Administration recognize MSG as a safe food additive?, the food industry is in search of alternative flavour potentiaters, due to the public concern regarding $\mathrm{MSG} .^{10}$ 
The objective of this study was to develop a dehydrated instant vegetable soup mix with no MSG, using a naturally MSG rich vegetable like tomato ${ }^{9 \cdot 11}$ and a mix of compatible ingredients such as spices (pepper, garlic), whey powder, vegetables (carrots, leeks, cabbage, onions), lentil powder, potato powder, corn flour, salt, sugar, vegetable fat, rosemary and celery.

\section{METHODS AND MATERIALS}

Preparation of raw materials: Raw materials such as tomato $\{$ Lycopersicon esculantum (Mill) var. Thilina\}, carrot (Daucus carota var. New coroda), leeks (Allium porrum. L.var. Large long summer), potato (Solanum tuberosum var. Cardinal), cabbage (Brassica oleracea var. Oxylus), big onion (Allium cepa var. Bombay red), pepper (Piper nigrum var. Local selections), celery \{Apium graveolens var. Dulce (Mill)\}, dhal (Lens culinaris ssp. Microspera) and garlic (Allium satioum var. Malai Poondu, imported from India) were purchased from the Kandy Central Market. Whey powder (Crino brand imported from Canada certified as Coliform $<10 / \mathrm{g}$, Salmonella-negative, $2.2 \%$ protein, $6.5 \%$ ash, $0.03 \%$ fat, $87 \%$ lactose, $4.2 \%$ moisture, $1.6 \%$ salt and $0.9 \mathrm{~mL}$ solubility index), vegetable fat, corn flour, sugar, salt (sodium chloride) and dried rosemary were purchased from Central Essence Suppliers and Keels Food City. All vegetables, potato, lentil and spices were processed at the Food Science and Technology Research Laboratory in the Faculty of Agriculture, University of Peradeniya immediately after purchasing using established procedures ${ }^{12-19}$. They were cut into required particle sizes using a vegetable processor (Robot coupe CL-30, Q3/PP25) and dehydrated in a cross-flow air cabinet drier (Model Phoenix 10- Tokyo, Japan). Dried materials were packaged in laminated pouches made with aluminum foil (Al foil), linear low-density polyethylene (LLDPE), and polyethylene terephthalate (PET) purchased from Varna Private Limited and kept in the refrigerator (SANYO MPR-S11) at $7^{\circ} \mathrm{C}$ until use.

Product formulation: Dehydrated materials were ground using a mixer grinder (Philips - HL3294/C) and sieved off (ASTM
E H-70 standard 'Frith' sieves, No. 35 and No 60) to produce the desired particle size (Table 1) and stored in pouches (PET/Alu foil/LLDPE). Many trials were conducted during product formulation. Ingredients were weighed and mixed in a special mixer instrument equipped with long necked flask with a brush, positioned horizontally, attached to the Rotovapor (R14, BUCHI Switzerland). Fat was mixed with sugar and salt before adding to the mixer. All ingredients were added to the mixer individually and mixed for $10 \mathrm{~min}$ per addition and the product finally mixed for $30 \mathrm{~min}$ to obtain a uniform blend.

Compositional analyses: Representative samples of the final formulation were homogenized at $70^{\circ} \mathrm{C}$ and analyzed for moisture (Fisher ISOEMP Vacuum oven, Model-281), crude fat (Ether extractable component from water bath model BS- 69, Yamato Scientific Co., Ltd.), crude protein (Kjeldhal nitrogen using 2006 Tecator digester and Kjeltec distilling unit, 1002), total ash (at $550^{\circ} \mathrm{C}$ in Muffle furnace, Model 28, Yamato Scientific Co., L.td.), crude fiber (Fibretec) total carbohydrate (by difference), calcium and iron (dry ashing measured by spectrophotometer - UV visible 1601 Shimaduzu), sodium (dry ashing measured by flame photometerCorning 410) according to the standard $\mathrm{AOAC}^{21}$ (Association of Official Analytical Chemists) procedures. Water activity (AW sprint, TH 500 Novasina) and $\mathrm{pH}$ (TOA $10 \mathrm{~N}$ ion meter $1 \mathrm{M}-40 \mathrm{~S}$ ) were also measured. All analyses were performed in six replicates. Standard Error of Means (SEM) was obtained using the SAS package.

Microbiological analysis: A sample of $50 \mathrm{~g}$ of product was diluted 10 fold with sterile Butterfield's phosphate buffer and blended in a pre-sterilized Waring Blender for $2 \mathrm{~min}$. One ml of extract was serially diluted $(1: 10,1: 100,1: 1000)$ with $\mathrm{KH}_{2} \mathrm{PO}_{4}(\mathrm{pH} 7.2)$. Dilutions were plated in triplicate on plate count agar (cooled to $42-45^{\circ} \mathrm{C}$ ) within 15 min from the time of original dilution. Plates were incubated at $35^{\circ} \mathrm{C}$ for $48 \pm 2 \mathrm{~h}$, and those containing 30-300 colonies were counted. Average counts were expressed as aerobic plate count cfu (colony forming unit) $/ g .{ }^{20}$

Table 1: Particle size of different ingredients used for formulating the soup mix

\begin{tabular}{lcc}
\hline Ingredients & Sieve no. & Maximum particle size (mm) \\
\hline $\begin{array}{l}\text { Tomato, celery stalk, leeks, carrots } \\
\text { Celery leaves, rosemary, potato, lentil, } \\
\text { cabbage, onion, pepper, garlic }\end{array}$ & 35 & 0.5 \\
\hline
\end{tabular}


Sensory analyses: The prepared soup $\operatorname{mix}$ and a commercial sample having similar ingredients including MSG were evaluated by 12 screened and trained panelists at the Industrial Technology Institute, Colombo. The products were evaluated based on the preference for colour, flavour and taste, mouth feel, consistency and overall acceptability using a 5-point hedonic scale where 1- represented the least preference and 5- the most preference. The soup samples were prepared in stainless steel pans. Sixty-six grams of formulated soup mix and seventy-five grams of commercial soup samples, as instructed in the package, were reconstituted in $1 \mathrm{~L}$ of water separately and simmered at $85^{\circ} \mathrm{C}$ for 5 minutes. Samples were evaluated by the panelists in individual booths within an hour of recommendation. Samples $(40 \mathrm{~mL})$ were served in small glass cups coded with three digit random numbers. The sensory data were subjected to Wilcoxon sign rank test using the SAS package.

\section{RESULTS AND DISCUSSION}

Selection of ingredients: Vegetable soup mixes should consist of at least four types of vegetables without predominance of any variety. Therefore, dehydrated carrot (moisture $4.3 \%$ ), leek (moisture $2.4 \%$ ), cabbage (moisture $3.5 \%$ ), tomato (moisture $3.6 \%$ ) and onion (moisture $3.1 \%$ ) were selected. Carrot was used as it is rich in carotenoids, $\beta$-carotene that has pro vitamin $A$ activity and is said to be able to reduce the occurrence of cancer. ${ }^{15}$ Moreover, carotenoids also possess anti-aging and anti-ulcer properties. ${ }^{21}$ Onion was chosen as it is considered a flavouring agent, a condiment, and a vegetable. ${ }^{22}$ Tomato was used mainly to improve flavour and therefore was added separately from the other vegetables. Glutamic acid, which is concentrated in the gelatinous pulp of ripened tomato fruit, is mainly responsible for its full flavour. ${ }^{22}$ Previous studies ${ }^{23}$ reported an increase in glutamic acid content from 28 (green) to 272 (red) $\mathrm{mg} / 100 \mathrm{~g}$ of fresh weight during the ripening of tomato. Contribution of glutamic acid to flavour characteristics of ripe tomato is well established. ${ }^{11}$ Perceived thickness is an essential requirement for any type of soup. ${ }^{24}$ Corn flour (moisture $5.2 \%$ ) and potato flour (moisture $3.71 \%$ ) were used as thickening agents to provide the desirable body and viscosity to the soup mix. ${ }^{25}$ Whey powder (moisture $4.23 \%$ ) was included as an emulsifying agent of oil in water soup system. In addition, it is used in the development of vegetable based soup mixes because it improves their nutritive and calorific values. ${ }^{26}$ The high lactose content in whey powder is reported to prevent moisture loss and retain freshness, thereby improving the shelf life of dry soup mixes. ${ }^{27}$ Furthermore, the flavour-enhancing ability of lactose in whey powder is reported to be similar to that of MSG. ${ }^{27}$ The use of lentil powder (moisture $3.21 \%$ ) improves the nutritional value of the soup mix because dried lentil seed $(100 \mathrm{~g})$ contains $20.2 \mathrm{~g}$ protein, $340 \mathrm{kcal}, 68 \mathrm{mg}$ calcium, $325 \mathrm{mg}$ phosphorous and vitamin B. ${ }^{28}$ Salt, used as a flavour enhancer, also acts as a preservative. ${ }^{22}$ Vegetable fat was incorporated since fat improves the desirable mouth feel, taste, and flavour in dry soup mixes. ${ }^{25}$ Garlic (moisture $3.36 \%$ ) has a pungent flavour. There are several advantages of consuming garlic. It lowers the blood cholesterol by $10-12 \%{ }^{30,31}$ and is able to reduce the occurrence of stomach cancer. ${ }^{31-34}$ Moreover, garlic has a therapeutic effect on blood coagulation and platelet aggregation $^{32,35}$ and acts as an antibacterial ${ }^{32}$ and antifungal agent. Herbs (rosemary-moisture $3.2 \%$ and celery leaves moisture $2.8 \%$ ) were used to improve the delicate flavour of the soup. ${ }^{9}$ Black pepper (moisture 3.5 $\%$ ) is used as a ground spice in seasoning because the piperine present in it stimulates the flow of saliva and gastric juices to aid digestion. ${ }^{9}$

Formulation of soup mix: In developing successful formulations, the decisions of a small group of experts are used in identifying flavour notes and combining ingredients. ${ }^{25}$ Therefore, in the initial stage of development, the prepared soup mix was evaluated for consistency, colour, flavour, mouth feel and overall acceptability by Food Technologists in the Department of Food Science \& Technology, University of Peradeniya (Table 2). According to them, formula 1 was found to possess a leafy flavour, probably due to the added spice mix which contained $23.8 \%$ celery leaves. Therefore, the second formula was prepared by reducing the amount of spice mix from $3 \%$ to $1 \%$, which balanced the leafy flavour. It was suggested to increase the tomato content and the pepper content slightly to improve taste. The third formula was too sweet to taste, although the added tomato content was increased from $6 \%$ to $7 \%$. According to previous studies ${ }^{37}$, sweetness of tomato soup was affected by added whey powder, probably due to lactose. In addition, lactose in aqueous solution tends to decrease the salty taste of sodium chloride. ${ }^{24}$ Therefore, the high percentage of whey powder that accounted for $20 \%$ of the formula was reduced to $18 \%$. In addition, the sugar content was reduced to $2 \%$ and salt content was increased to $12 \%$. The amount of lentil powder was increased by $4 \%$ accounting for $12 \%$ of the formulation to compensate for the total weight reduction. Fat was reduced by $2 \%$, because tomato flavour was affected by both added protein and fat. ${ }^{36}$ The fourth formula was satisfactory in terms of all quality attributes. 
Table 2: Percentage ingredients used in different formulations of instant soup mixes

\begin{tabular}{|c|c|c|c|c|}
\hline \multirow[t]{2}{*}{ Ingredients $\%$} & \multicolumn{4}{|c|}{ Formulations } \\
\hline & 1 & 11 & 111 & lV \\
\hline Salt & 10 & 10 & 10 & 12 \\
\hline Tomato & 6 & 6 & 7 & 7 \\
\hline Sugar & 9 & 9 & 6 & 2 \\
\hline Fat & 6 & 6 & 6 & 4 \\
\hline Potato flour & 7 & 8 & 8 & 10 \\
\hline Lencil flour & 6 & 6 & 8 & 12 \\
\hline Whey powder & 20 & 20 & 20 & 18 \\
\hline Corn flour & 8 & 9 & 9 & 9 \\
\hline Spice mix ${ }^{2}$ & 3 & 1 & 1 & 1 \\
\hline Dried vegetable $\mathrm{mix}^{\mathrm{b}}$ & 25 & 25 & 25 & 25 \\
\hline
\end{tabular}

Pbysico chemical and microbiological analysis: Moisture content and water activity of the developed soup mix was $3.8 \%$ and 0.43 at $25^{\circ} \mathrm{C}$, respectively. According to $\mathrm{Jay}^{37}$, water activity below 0.6 is desirable for dried foods since it retards both microbial growth and browning reactions during storage. Microbiological analysis revealed that aerobic plate count of the developed soup mix was $2.3 \times 10^{3} \mathrm{cfu} / \mathrm{g}$. Therefore, the product is microbiologically safe since total count of dehydrated soups should generally be less than $1 \times 10^{4}$ cfu/g. ${ }^{37}$ Higher number of microbial counts in dehydrated products is due to the concentration of organism on a per gram basis along with product concentration..$^{38}$ Data on compositional analysis (Table 3) revealed that the mean value of crude fat content was $4.1 \%$. This amount is slightly higher than the added amount of fat $(4 \%)$ because the other added ingredients contributed some amount of fat. High protein content of the mix is due to the added lentil powder and whey powder. Added salt (12\%), whey powder (6.58\% which contains $1.6 \%$ salt), and pre-drying treatment of cabbage (soaking in $6 \%$ salt and $3 \%$ sugar) may have contributed considerably to the higher ash content. Moreover, high sodium and potassium contents in lentil powder, $29 \mathrm{mg}$ and $780 \mathrm{mg}$, respectively ${ }^{28}$, may have also contributed to the high content of total ash in the soup mix. However, contribution of calcium and iron to total ash content was rather low, probably due to leaching losses during blanching of vegetables prior to dehydration. Although the soup mix contained $12 \%$ salt, during preparation it gets diluted up to $1.8 \%$ (15 g per serving). Based on the $\mathrm{pH}$ value, 4.7 , the product can be categorized as a low acid food. Though Clostridium perfringens and Clostridium botulinum are the problematic organisms in low acid food, their growth in dried products is less likely due to low water activity. ${ }^{37}$ The method of handling of the reconstituted soup is crucial, as $\mathrm{Cl}$. perfringens can grow at temperature up to $55^{\circ} \mathrm{C}$ in reconstituted products..$^{39}$ As such it is imperative that the reconstituted soup be consumed soon after reconstitution while it is warm.

Table 3: Composition of the developed soup mix

\begin{tabular}{|c|c|}
\hline Component & $\%$ Dry weight basis \\
\hline Protein " & $16.10 \pm 0.02$ \\
\hline Fat ${ }^{2}$ & $4.10 \pm 0.13$ \\
\hline Fiber * & $2.70 \pm 0.01$ \\
\hline Total ash ${ }^{2}$ & $18.30 \pm 0.02$ \\
\hline Calcium " & $0.17 \pm 0.01$ \\
\hline $\operatorname{Iron}(\mathrm{mg} / 100 \mathrm{~g})^{\mathrm{a}}$ & $4.61 \pm 0.09$ \\
\hline Carbohydrate ${ }^{\mathrm{b}}$ & 55 \\
\hline Calorific value $(\mathrm{kcal} / \mathrm{g})$ & 321 \\
\hline
\end{tabular}

Reconstitution of soup mixture: Commercially available soup mixes are reconstituted by adding water in ratios ranging from 1:20 to $1: 15$. Reconstitution at a ratio of $1: 20$ resulted in a soup that was watery in appearance and less in flavour and a ratio of 1:15 produced a thick soup. The ratio of 1:15 was found to be acceptable as the reconstituted soup possessed a desirable consistency and flavour. 
Sensory evaluation: A commercial vegetable soup containing MSG and the developed soup in this study were not significantly different in terms of flavour $(p=0.2662)$, mouth feel $(p=0.9487)$, colour $(p=0.7213)$, consistency $(p=0.0568)$ and overall acceptability $(p=0.8061)$ as reflected by the mean scores. This revealed that the different ingredients and their quantities used in formulating the soup mixture are comparable to that of a vegetable soup containing MSG. Thus, the soup mix developed in this study is better than those containing MSG, particularly for those who are sensitive to MSG.

\section{References}

1 Komarik S.L., Luh B.S. \& Sutton A.K. (1975). Vegetables in soups in :Commercial Vegetable Processing. (Eds B.S. Luh \& J. G. Woodroof) pp. 729-745. AVI Publishing Co., Westport, Connecticut, USA.

2 Fairbrother J.G. (1968). Compressed formulated products; A new concept in dehydrated foods. Food Technology 22(12): 100-102

3 Thorner M.E. (1973). Convenience and Fast Food Handbook. pp. 229-245. AVI Publishing Co., Westport, Connecticut, USA.

4 Binsted R. \& Devey J.D. (1970). Soup Manufacture; Canning Dehydration and Quick Freezing. (3rd Edition) pp. 48. Food Trade Press, London.

5 Halpern B.P. (2000). Glutamate and flavor of foods. Journal of Nutrition 130 (4S): 910 S-914S.

6 Altug T. \& Demirag K. (1993). Influence of monosodium glutamate on flavor acceptability and on the reduction of sodium chloride in some ready-made soups. Chemi Mikrobiologie Der Lebensmittel 15(5/6): 161-164.

7 Schiffman S.S. (1998). Sensory enhancement of foods for elderly with monosodium glutamate and flavors. Food Review International $14(2 / 3): 321-333$.

8 Kemp S.E. \& Beauchamp G.K.(1994). Flavor modification by sodium chloride and monosodium glutamate. Journal of Food Science 59(3): 682-686.

9 Hanas O.P. (1994). Seasoning ingredients. In: Handbook of Industrial Seasonings. (Eds E.W. Underriner \& I.R. Hume) Pp. 20-41. Chapman \& Hall, Bishopbriggs, Glasgow, UK

10 Hegenbart S.L. (1998). Alternative enhancers. Food Product Design $7(11): 60-71$.

11 Freydberg N. \& Gorther W.A. (1982). The Additives Book, pp. 555-557. Bantam Books, Inc. New York.

12 Sagar V.R. \& Maini S.B. (1997). Studies on packaging and storage of dehydrated onion slices. Indian Food Packer 51(1): 5-10.

13 Luh B.S. \& Meehan JJ. (1975). Vegetable dehydration. In: Commercial Vegetable Processing. (Eds B.S. Luh \& J. G. Woodroof) pp 392-412. AVI Publishing Co., Westport, Connecticut, USA.

14 Ambrose B.C.P. \& Srinarayana V.V. (1998). Studies on the dehydration of garlic. Journal of Food Science 35(3): 242-244.

15 Sharma G.K., Semual A.D \& Arya S.S. (2000). Effects of processing treatments on the carotenoids composition of dehydrated carrots. Journal of Food Science and Technology. 37(2):196-200.

16 Kordylas J.M. (1991). Processing Fruit and Vegetable by Dehydration. In: Processing and Preservation of Tropical and Sub Tropical Foods. pp. 199-217. Macmillan Education, Hampshire, England.

17 Van Arsdel B.S.W.B., Copley M.J. \& Margan J.R.A.I. (1973). Vegetables. In: Food Debydration (Ed B. Feinberg) pp. 56-58. AVI Publishing Co., Westport, Connecticut, USA.
18 Gupta D.K.D., Rao N.B. \& Jayaraman K.S. (1999). Improvement in rehydration and shelf stability of hot air dried and sun dried cabbage by pre-drying treatment. Indian Food Packer 53 (6):51-60.

19 Marwaha R. S. \& Sandu S.K. (2001). Preparation of potato flour and its quality characteristics by predrying treatment. Indian Food Packer 55 (4):49-54.

20 AOAC. (1996). Official Methods of Analysis, (16 Edition) Association of Official Analytical Chemists, International, Arlington, VA.

21 Speak A.J., Speak-Saichua S. \& Schreurs W.H.P. (1988). Total carotenoids and carotene contents of Thai vegetables and the effect of processing. Food Chemistry 27:245-247.

22 Underriner E.W. (1994). An Introduction. In: Handbook of Industrial Seasonings. (Eds E.W. Underriner \& I.R. Hume) pp. 119. Chapman \& Hall, Bishopbriggs, Glasgow, UK.

23 Hobson G.E. \& Davies J.N. (1971). The tomato. In: The Biochemistry of Fruits and Their Products, Vol. 2. (Ed A.C. Hulme) pp. 437-450. Academic Press, London.

24 Rosette T.R., Kendregan S.L., Gao Y., Schmdt S.J. \& Klein B.P. (1996). Thickening agents' effects on sodium binding and other taste qualities of soup systems. Journal of Food Science 61 (5): 1099-1104

25 Nair J.H. \& Warren D.H. (1973). Dry soups and other dry mixes. In: Food Debydration. (Eds W.B. Van Arsdal, W.B. Copley \& M.J. Copley) pp. 437-464. AVI Publishing Co., Westport, Connecticut, USA.

26 Singh S, Landkanl B.G., Kumar A. \& Mathur B.N. (1994). Whey utilization for the manufacture of ready to serve soups. Indian Joumal of Dairy Science 47(6):501-505.

27 Keay J. (1971). Whey powder. Food Manufacture 11(11):36, 41, 43

28 Duke J.A. (1981). Handbook of legumes of world economic importance, pp. 110-113. Plenum Press, New York.

29 Alder A.J. \& Holub B.J. (1997). Effect of garlic and fish - oil supplementation on serum lipid and lipoprotein concentrations in hypercholesterolemic men. American Journal of Clinical Nutrition 65 (4):445-450.

30 Holzgartner H., Schmidt U. \& Kuhn U. (1992). Comparison of the efficacy and tolerance of garlic preparation vs. bezafibrate. Arzneimittelforschung 42: 1473-1477.

31 Lau B.H., Tadi P.P. \& Tosk J.M. (1990). Allium sativum (garlic) and cancer prevention. Nutrition Researcb 10(4):937948.

32 Han J., Lawson L., Han G. \& Han P. (1995). A spectrophotometric method for quantitative determination of allicin and garlic thiosulfinates. Analytical Biochemistry 225 (2): $157-160$.

33 Milner J.A. (1996). Garlic: its anticarcinogenic and antitumorigenic properties. Nutrition Reviews 54(1): S82-S86.

34 Lawson I.D. (1998). Garlic: A Review of its medicinal effects and indicated active compounds. In: Phytomedicines of Europe: Their Chemistry and Biological Activity (Eds L.D. Lawson \& R. Bauer) pp. 176-209. Washington, DC.

35 Lawson L.D. (1992). Bioactive organosulfer compounds of garlic and garlic product: Role in reducing blood lipids. In: Human Medicinal Agents from Plants, Symposium Series 534 (Eds A.D. Kinghom \& M.F. Balandrin) pp. 306-330. Washington, DC.

36 Rosette T.R., Kendregan S.L. \& Klein P.B. (1997). Fat, protein, and mineral components of added ingredients affect flavor qualities of tomato soups. Journal of Food Science 62(1): 190-193.

37 Jay J.M. (1992). Modern Food Microbiology. Fourth Edition pp. 356370. Chapman \& Hall, 115 Fifth Avenue, New York.

38 Fanelli, M.J., Peterson A.C. \& Gunderson M.F. (1965). Microbiology of dehydrated soups. I. A survey. Food Techology 19 (5):83-86.

39 Nakamara M. \& Kelly K.D. (1968). Clostridium perfringens in dehydrated soups and sauces. Journal of Food Science 33 (2):424-426. 